\title{
Pentingnya Meningkatkan Kemampuan Berbahasa Inggris Para Mudabbirah di Pondok Pesantren
}

\author{
Muhammad Amin*, Lalu Thohir, Mahyuni \\ Program Studi Pendidikan Bahasa Inggris FKIP Universitas Mataram \\ Jl. Majapahit 62 Mataram, Nusa Tenggara Barat 83125, Indonesia
}

\section{Article history}

Received: 08-10-2020

Revised: 20-10-2020

Accepted: 26-10-2020

*Corresponding Author:

Muhammad Amin, Program Studi Pendidikan

Bahasa Inggris FKIP

Universitas Mataram,

Nusa Tenggara Barat,

Indonesia

Email:

aminmuhammad@unram.ac.id
Abstract: Mudabbirah, an Arabic word which means 'coach' is part of an Islamic boarding school management. Different from any other personnel of school management, Mudabbirah are selected among students of the 11th grade. This element of management is usually based in each room where students live and is responsible for controlling the day-to-day activities of other students staying in the room. In addition to tasks such as ensuring discipline, mudabbirah is also given a responsibility to coach their juniors in learning foreign languages (in this particular school Arabic and English). Due to the important role this school element plays, this training was held in order to improve mudabbirah language mastery as well as their teaching methodology. The findings show that mudabbirah showed enthusiasm which is reflected by their attendance and activeness during the training. By doing so it is hoped that they can perform their duty better as a result of better developed language knowledge and skills in English and at the same time are skillful coach for their peers.

Keywords: management; mudabbirah; training; coaching; skill

Abtrak: Mudabbirah (untuk perempuan dan untuk laki-laki Mudabbir) adalah sebuah kata dalam Bahasa Arab yng berarti pembimbing. Di pondok pesantren para mudabbirah merupakan salah satu komponen maejemen yang sangat penting dan biasanya mereka yang ditugaskan dipilih dari kelas 11. Para mudabbirah ditempatkan di masing-masing kamar dan memiliki tanggung jawab untuk mengawasi kehidupan keseharian para santriwati. Disamping tugas menegakkan displin, elemen pondok pesantren ini juga memliki tugas untuk membantu melatih para santriwati dalam mempelajari Bahasa asing. (di pondok pesantren ini dua Bahasa yang dikembangkan adalah Bahasa Arab dan Bahasa Inggris). Karena pentingnya peran yang dimainkan oleh mudabbirah maka pelatihan ini diadakan untuk meningkatkan kemampuan berbahasa sekaligus juga kemampuan dan keterampilan mereka dalam metode mengajarkan Bahasa Inggris. Hasil kegiatan menunjukkan bahwa para mudabbirah sangat antusias dalam mengikuti kegiatan yang bisa dilihat dari kehadiran dan keaktifan mereka selama mengikuti kegiatan. Dari kegiatan pelatihan ini diharapkn kemampuan berbahasa Inggris para mudabbirah meningkat dan kemempuan membimbing adik-adik kelas mereka menjadi semakin baik.

Kata Kunci: menejemen; mudabbirah; pelatihan; pembimbingan; keterampilan 


\section{PENDAHULUAN}

Tujuan pembelajaran bahasa Inggris sebagaimana tercantum dalam standar kompetensi lulusan dalam aspek pengetahuan dan keterampilan adalah terdapatnya lulusan yang memiliki kemampuan dalam memahami dan mengungkapkan makna dalam bahasa Inggris baik secara lisan maupun tulisan dalam situasi dan konteks yang berbeda (Kompetensi Dasar Sekolah Menengah Pertama (SMP)/Madrasah Tsanawiyah (MTs), 2013; Kompetensi Dasar Sekolah Menengah Atas (SMA)/Madrasah Aliyah (MA), 2013). Dari uraian ini jelas terlihat bahwa hasil belajar yang diharapkan bukan hanya terbatas pada penguasaan ilmu tentang bahasa (knowing about the language) tetapi juga keterampilan menggunakan bahasa secara lancar dan berterima (ability to use the language).

Proses akuisisi bahasa merupakan proses yang kompleks yang tidak hanya memerlukan waktu yang cukup bagi siswa untuk memperoleh pajanan terhadap bahasa yang dipelajari tetapi juga kesempatan untuk menginternalisasi input bahasa yang diperoleh melalui proses eksperimentasi dalam meggunakan bahasa tersebut. Dengan kata lain keterampilan berbahasa, sebagaimana keterampilan pada umumnya, menghendaki bukan hanya pengetahuan tentang bahasa yang diperoleh berupa input bahasa akan tetapi kesempatan untuk mengakuisisinya melalui praktek menggunakan bahasa dimaksud. Dalam hal ini Scrivener (2005) menganjurkan dominasi prosentase waktu untuk pengulangan dan penguatan terhadap input yang sudah diberikan sebelumnya (95\%) sedangkan pemberian input yang baru tidak lebih dari $5 \%$.

Guru memainkan peran sentral dalam proses pembelajaran siswa. Bahkan diantara berbagai factor yang potensial mempengaruhi pembelajaran siswa, seperti pendidikan orang tua, keadaan ekonomi, dan sebagainya, guru memiliki pengaruh terbesar (Darling-Hammond dkk, 2001). Secara lebih rinci penelitian Hattie (2003) menemukan bahwa 30\% dari capaian pembelajaran siswa dipengaruhi/ditentukan oleh guru. Dengan kata lain, kalau seorang guru memiliki kualitas yang baik maka sudah ada sepertiga potensi kesempatan siswa untuk mencapai kompetensi pembelajaran yang diharapkan. Begitu juga sebaliknya apabila kualitas guru tidak mendukung, maka 30\% potensi capaian belajar siswa sudah terhambat.

Pondok pesantren Nurul Haramain Putri Narmada adalah pondok pesantren yang mengharuskan semua santriwatinya untuk tinggal di area pesantren. Hal ini memungkinkan pihak sekolah untuk mengelola dan mengatur waktu santriwati melaksanakan pembelajaran baik pebelajaran ilmu umum dan juga ilmu agama. Di dalam lingkungan pondok, secara umum proses pembelajaran santriwati dilakukan di dua tempat yang berbeda. Tempat pertama adalah di ruang kelas dan yang kedua di luar kelas. Untuk tempat kedua ini mereka terkadang belajar di depan ruang tidur mereka atau di tempat lainnya, seperti di berugak, di aula dan sebagainya.

Pembelajaran di ruang kelas diisi dengan pembelajaran yang didasarkan pada mata pelajaran yang ditetapkan oleh kurikulum departemen agama dan dibimbing oleh guru mata pelajaran sedangkan untuk pembelajaran di ruang kelas berfokus pada ilmu pengetahuan dan keterampilan penunjang dan akan banyak dilakukan oleh kakak kelas mereka (santriwati kelas 5) yang juga merupakan penanggung jawab kamar. Pembimbing/penanggug jawab masing-masing kamar ini disebut sebagai mudabbirah dengan jumlah 2 orang untuk masing-masing kamar. Dari total keseluruhan jumlah santri yang belajar di Pondok Pesantren ini (1290 orang) ditunjuk sejumlah 204 santriwati sebagai mudabbirah (komunikasi dengan seorang pengasuh: Ust. Nita Kasih, Desember 2019). Para pelajar/santri ini terbagi dalam 12 rayon. 
Para mudabbirah ini memiliki beberapa tugas dan tanggung jawab. Tugas utama mudabbirah adalah memonitor keberadaan adik-adik santriwati menjaga kebersihan dan juga menerapkan disiplin. Disamping tugas utama itu mereka juga bertanggung jawab membina dan membimbing mereka dalam belajar berkomunikasi dalam Bahasa asing. Di pondok pesantren ini ada dua Bahasa asing yang menjadi prioritas: Bahasa Arab dan Bahasa Inggris.

Ada beberapa tujuan diadakannya pelatihan ini. Kegiatan Pengabdian pada Masyarakat ini bertujuan untuk: (a) Meningkatkan pengetahuan dan keterampilan khalayak sasaran (para mudabbirah Pondok Pesantren Putri Nurul Haramain) dalam berbahasa Inggris, terutama Bahasa Inggris lisan. (b) Mengenalkan pada khalayak sasaran metode dan strategi pembelajaran Bahasa Inggris yang komunikatif dan berpusat pada siswa (learner-centred approach).

Dari kegiatan Pengabdian pada Masyarakat ini diharapkan: (a) Khalayak sasaran, para mudabbirah di Pondok Pesantren Nurul Haramain Putri, memiliki pengetahuan dan keterampilan berbahasa Inngris yang meningkat; (b) Khalayak sasaran, para mudabbirah di Pondok Pesantren Nurul Haramain Putri mengenal dan telah mengalami proses pembelajaran Bahasa Inggris komunikatif sehingga mereka lebih efektif dalam membantu adik-adik santriwati mereka dalam belajar Bahasa Inggris.

Sebagaimana disampaikan sebelumnya peran para mudabbirah di pondok pesantren ini cukup sentral dalam proses pembelajaran Bahasa di pondok. Hal ini tampak dari tugas dan tanggung jawab yang mereka emban dan keberadaan mereka yang sangat dominan bersama para santriwati. Waktu yang mereka pergunakan bersama santriwati sangat banyak sehingga mereka memiliki potensi yang besar untuk membentuk para santriwati, termasuk dalam peningkatan kemmapuan berbahasa mereka. Akan tetapi dari beberapa kali pengamatan yang tim pengabdian masyarakat ini lakukan terhadap proses pembimbingan berbahasa oleh para mudabbirah, tampak bahwa mereka masih memerlukan peningkatan kemampuan, baik dalam hal berbahasa maupun pendekatan pembelajaran. Secara lebih rinci permasalahan-permasalahan dimaksud dapat diuraikan sebagai berikut:

1. Para mudabbirah belum cukup cakap dalam menggunakan Bahasa Inggris, baik dalam hal diksi, tata Bahasa, pelafalan dan intonasi.

2. Proses pembelajaran bahasa juga masih didominasi oleh proses mekanikal, yaitu proses yang lebih menekankan pada akurasi dan penguasaan pola. Hal ini menyebabkan munculnya keengganan mencoba menggunakan Bahasa Inggris diantara para santriwati karena dipenuhi rasa kekhawatiran membuat kesalahan.

3. Disamping itu para mudabbirah mengakui kalau selama ini belum mendapat pelatihan tentang pendekatan akuisisi Bahasa yang komunikatif dan 'learner-centred'.

Berdasarkan paparan di atas maka kami mengadakan pelatihan yang berfokus pada peningkatan kemampuan berbahasa Inggris para mudabbirah melalui sebuah proses yang memungkinkan mereka mengalami sendiri proses pembelajaran yang komunikatif dan berpusat pada siswa.

\section{METODE}

Khalayak sasaran strategis dari kegiatan Pengabdian pada Masyarakat ini adalah para mudabbirah di Pondok Pesantren Nurul Haramain Putri, Narmada Lombok Barat. Pemilihan khalayak sasaran didasarkan pada pertimbangan bahwa mudabbirah ini memegang peranan penting dalam membina dan menigkatkan kemampuan berbahasa Inggris para santriwati karena sebagaimana 
diuraikan sebelumnya mereka memiliki banyak waktu dan kesempatan bersama para santriwati (adikadik kelas dibawahnya). Dengan dilaksanakannya program pengabdian ini diharapkan pengetahuan dan keterampilan khalayak sasaran akan meningkat baik sebagai pengguna Bahasa Inggris dan juga orang yang akan memfasilitasi adik-adik santriwatiya dalam belajar Bahasa Inggirs.

1. Metode yang digunakan

Kegiatan Pengabdian pada Masyarakat ini dilakukan dengan metode pelatihan. Metode ini diimplementasikan dengan mengetahui kompetensi awal para peserta, menentukan target kompetensi, dan menyusun rencana materi dan kegiatan untuk mencapai kompetensi target. Metode ini juga mengadopsi prinsip 'take out and get in'.

2. Langkah Implementasi

Secara lebih rinci langkah-langkah implementasi pelatihan untuk mencapai tujuan yang dicanangkan meliputi:

a. Pengumpulan informasi tentang kemampuan berbahasa Inggris para santriwati (melalui sebuah pre-test). Test awal ini akan mencakup test vocabulary, reading dan juga listening. Diharapkan dari pemberian tes awal ini akan diperoleh informasi awal tentang kemampuan berbahasa peserta.

b. Penyusunan silabus. Penyusunan silabus merupakan langkah berikutnya. Dengan menggunakan data yang diperoleh dari pre-test akan disusun silabus yang akan digunakan sebagai pedoman pelaksanaan pelatihan.

c. Pelaksanaan pelatihan. Pelaksanaan pelatihan merupakan program utama pelaksanaan kegiatan pengabdian kepada masyarakat ini. Program ini berisi presentasi materi yang mencakup presentasi tentang language systems dan juga language skills dengan penekanan pada komunikasi lisan dan pembelajaran yang berpusat pada siswa.

d. Post test. Disamping observasi yang dilakukan selama pelaksanaan pelatihan, untuk mengetahui sejauh mana peningkatan kemampuan siswa dalam berbahasa Inggris maka akan diberikan sebuah post-test. Post-test ini akan lebih terfokus pada evaluasi kemampuan peserta mengerjakan tes tulis.

e. Observasi pelaksanaan pembinaan oleh mudabbirah ke santriwati binaan. Setelah proses pelatihan berlangsung, tim pengabdian ini akan melakukan observasi secara acak terhadap pelaksanaan pembimbingan belajar Bahasa Inggris oleh peserta pelatihan. Hal ini bertujuan untuk melihat sejauh mana hasil pelatihan dapat diimplementasikan oleh para peserta.

f. Review hasil pelakasanaan pembinaan oleh mudabbirah ke santriwati binaan. Kegiatan ini bertujuan untuk merefleksikan proses pembinaan yang telah dilakukan para mudabbirah. Kegiatan ini akan dilakukan dalam bentuk focus group discussion (FGD). Prinsip take out and get in juga akan diterapkan disini. Para mudabbirah akan diminta memaparkan bagaimana proses pembinaan yang telah dilakukan, bagian mana yang mereka anggap telah berjalan sesuai harapan dan juga kesulitan yang mereka rasakan. Partisipasi aktif peserta dan juga masukan dari tim observasi diharapkan dapat memberikan solusi bagi masalah dalam proses pembinaan dalm belajar Bahasa Inggris dengan santriwati.

\section{Partisipasi Mitra}

Mitra dari kegiatan ini adalah pimpinan Pondok Pesantren Nurul Haramain. Peran dari Pihak pondok sangat penting dalam membantu proses perencanaan dan implementasi program baik mengenai peserta yang ditugaskan, waktu, serta tempat pelaksanaan pengabdian. 
4. Pelaksanaan kegiatan

Sebagaimana direncanakan kegiatan pengabdian kepada masyarakat ini dilakukan dengan pertama-tama mengadakan pertemuan dengan pihak pondok pesantren, terutama yang mebidangi bidang pembinaan kebahasaan. Kebetulan di pondok pesantren ini ada divisi yang mengurusi bidang kebahasaan yang mencakup Bahasa Indonesia, Bahasa Arab dan Bahasa Inggris. Dalam pertemuan ini dibicarakan tentang program pelakasanaan kegiatan pembinaan keterampilan berbahasa, termasuk secara khusus program kegiatan pembelajaran Bahasa Inggris. Dari sinilah diperoleh informasi tentang evaluasi kemampuan berbahasa Inggris para mudabbirah serta masalah-masalah yang masih mereka hadapi. Sebagai tindak lanjut kegiatan dimaksud maka disepakati diadakannya pertemuan awal dengan para mudabbirah yang bertujuan untuk: pertama mengadakan perkenalan dan sekaligus mencari informasi lebih rinci tentang kebutuhan berbahasa dari para mudabbirah tersebut.

\section{HASIL DAN PEMBAHASAN}

Dari hasil diskusi dengan para mudabbirah, yang sebelumnya juga didahului informasi dari Pembina bidang keterampilan berbahasa, maka diidentifikasi bahwa kebutuhan berbahasa para mudabbirah ini berfokus pada peningkatan kemampuan berbahasa lisan yang terdiri dari keterampilan berbicara (speaking) dan menyimak (listening). Namun tentu saja mengingat berbahasa pada intinya adalah kemampuan menguasai kosa kata (vocabulary), maka unsur 'system' dalam berbahasa ini juga akan menjadi prioritas proses pembelajaran meskipun tentu saja kegiatan akuisisi kosa kata ini tidak harus ekspilisit.

1. Kegiatan pembelajaran

Dibawah ini digambarkan bagaimana proses mudabbirah dalam mengikuti kegiatan familiarisasi/pengenalan metode sekaligus juga bagaiman memperaktekkannya.

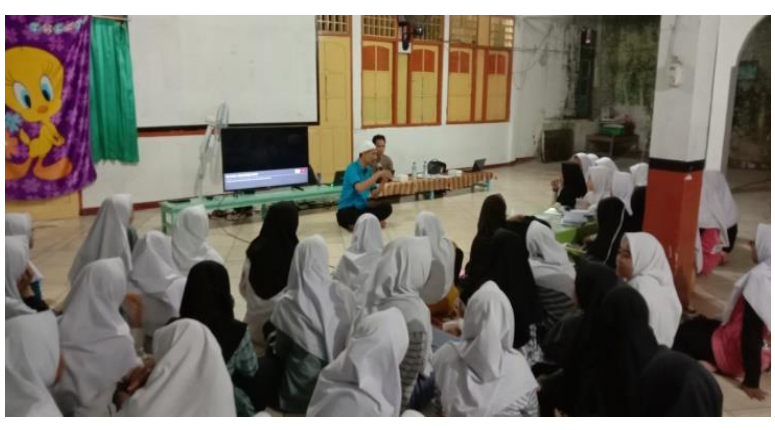

Gambar 1: Pelaksanaan Kegiatan

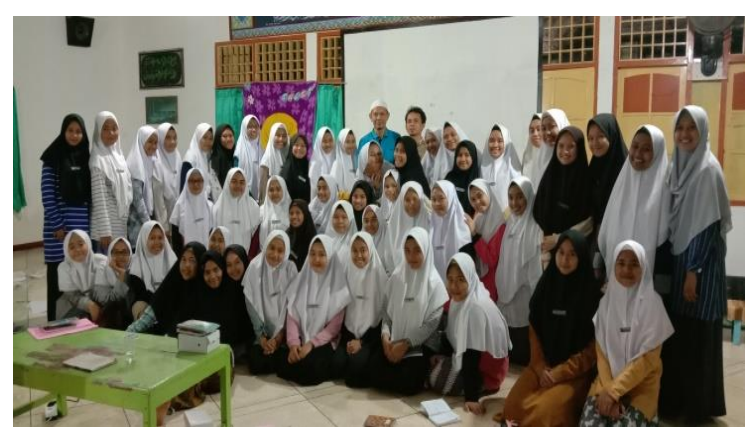

Gambar 2: Penutupan Kegiatan

Dalam hal pendekatan pembelajaran yang diterapkan diusahakan sebanyak mungkin dilakukan dengan pendekatan berbasis siswa (learner-centred approach). Pendekatan ini menghendaki pelibatan siswa seccara maskimal dalam seluruh proses pembelajaran, baik pada saat pengenalan (presentation), praktek penggunaan terbatas (practice) dan penggunaan secara lebih luas (production). Secara lebih sederhana dapat dikatakan bahwa pada semua langkah pembelajaran sebanyak mungkin siswa dilibatkan baik secara kognitif maupun afektif. Misalnya, sebelum sebuah topik dibahas maka hal pertama yang dilakukan adalah menggali pengetahuan awal yang dimiliki siswa tentang topik tersebut, dan inipun dilakukan dengan cara menerapkan prinsip belajar kolaboratif dan komunikatif. Pendekatan belajar kolaboratif muncul dengan mengisntruksikan para siswa bekerja secara 
berpasangan atau kelompok kecil sedangkan prinsip komunikatif diimplementasikan dengan kegiatan yang membuat masing-masing mereka mengungkapkan kebutuhan berkomunikasi dalam Bahasa Inggris terutama Bahasa lisan.

Dalam hal konten, sebagaimana dijelaskan sebelumnya, kegiatan pembelajaran difokuskan pada peningkatan kemampuan mendengar dan berbicara, yang ditunjang dengan peningkatan jumlah kosakata. Materi belajar banyak memuat topik sehari-hari (pekerjaan, hobi, notice, dsb) dengan asumsi secara content mereka memiliki cukup pengetahuan. Dengan demikian mereka dapat dapat lebih terfokus pada cara mengekspresikan diri (how).

Karena peserta adalah para mudabbirah yang memiliki tanggung jawab membina adik-adik santriwati mereka, maka disamping materi yang meningkatkan kemampaun berbahasa, materi pelatihan juga mencakup peningkatan pemahaman dasar metode pengajaran Bahasa. Untuk tujuan ini maka materi pelatihan membahas tentang prinsip-prinsip dasar dalam mempelajari sebuah Bahasa seperti prinsip 'scaffold', komunikatif. dan learner-centredness. Scaffolding adalah prinsip belajar yang merupakan 'assisted learning' menghendaki adanya proses yang menerapkan langkah-langkah pembelajaran yang membantu seorang pembelajar dapat memhami sesuatu dengan sebab bantuan orang/benda lain (Vygotsky dalam Harmer, 2007), dan juga 'cognitive constructivism' yang meyakini proses pembelajaran terjadi tidak terlepas pengetahuan sebelumnya yang dimiliki siswa (Piaget dalam Kapur, 2017). Disamping itu sebagai implementasi prinsip 'scaffolding' aktivitas pembelajaran dimulai dari yang sederhana ke yang lebih rumit dan dari yang mudah ke yang lebih sulit. Prinsip komunikatif menghendaki penerapan pembelajaran yang akan merangsang atau memacu peserta berkomunikasi dengan peserta yang lain. Sedang learner-centredness akan mempertimbangkan/ menjadikan para peserta sebagai dasar memutuskan materi dan kegiata pembelajaran yang dilakukan.

Selain itu untuk menunjang kegiatan pembelajaran, hal-hal yang dianggap dapat menghambat proses pembelajaran, seperti munculnya situasi/atmosfir pembelajaran yang tidak kondusif seperti kekhawatiran membuat kesalahan (fear of making mistakes), saling mengejek akibat karena kesalahan (wooing among students), dan juga kurangnya keberanian mengekspresikan diri (lack of courage) berusaha disingkirkan. Para siswa dimotivasi dan diberikan informasi tentang faktor-faktor yang dapat menunjang serta menghambat proses akuisisi sebuah bahasa.

Secara singkat dapat dikatakan bahwa proses pelatihan berusaha memenuhi kebutuhan berbahasa para mudabbirah dan dilakukan dengan atmosfir pembelajaran yang kondusif. Disamping input Bahasa secara langsung oleh para tutor, mereka juga dipajankan dengan input Bahasa dari penutur asli (native speaker) melalui rekaman-rekaman. Dalam hal membangun proses yang kondusif para peserta pelatihan diarahkan agar merasa menjadi bagian dari proses yang dilakukan, yang saling membutuhkan, dan keberhasilannya ditunjang oleh kemauan dan keinginan bekerjasama terutama dalam hal latihan menggunakan Bahasa Inggris.

\section{KESIMPULAN DAN SARAN}

Para mudabbirah sangat antusias dalam mengikuti kegiatan. Hal ini terbukti dari presensi mereka dan keaktifan mereka dalam mengikuti kegiatan. Secara umum mereka tidak memiliki kendala dalam hal keberanian mengekspresikan diri dalam Bahasa Inggris. Mereka sudah terbiasa dengan kegiatan berlatih berbahasa Ingggris dalam kegiatan sehari-hari. Meskipun dari sisi afektif dan kelancaran (fluency) mereka tidak banyak masalah, mereka masih memerlukan pengetahuan dan keterampilan dalam hal keakuratan berbahasa (accuracy). Fokus pelatihan yang berorientasi pada konten dan metode dirasa sangat tepat karena memang keduanya sangat dibutuhkan oleh para 
santriwati yang ditugaskan sebagai mudabbirah. Disamping kepada para mudabbirah yang sedang bertugas, pelatihan seperti ini seharusnya juga dilakukan kepada para calon mudabbirah sehingga pada saat mereka bertugas nantinya mereka sudah memiliki kemampuan dan keterampilan berbahasa Inggris yang cukup. Dengan demikian mereka dapat menularkan ilmu dan keterampilan berbahasa dengan lebih lancer dan akurat.

\section{DAFTAR PUSTAKA}

Darling-Hammond, L., LaFors, J. dan Snyder, J. 2001. Educating Teachers for California's future. Teacher Education Quarterly, 28 (1): 9-55.

Departemen Pendidikan dan Kebudayaan. 2013. Kompetensi Dasar Sekolah Menengah Atas (SMA/Madrasah Aliyah (MA). Jakarta: Departemen Pendidikan dan Kebudayaan

Departemen Pendidikan dan Kebudayaan. 2013. Kompetensi Dasar Sekolah Menengah Pertama (SMP/Madrasah Tsanawiyah (MTs). Jakarta: Departemen Pendidikan dan Kebudayaan

Harmer, J. 2012. The Practice of English Language Teaching ( $4^{\text {th }}$ Edition). Essex: Pearson Education Limited:

Hattie, J. 2003. Teachers Make a Difference: What is the research evidence? Retrieved on June 9, 2012 from https://cdn.auckland.ac.nz/assets/education/hattie/docs/teachers-make-adifference-ACER-(2003).pdf.

Kapur, V. 2017. Understanding constructivism in Second language context. Scholarly Research Journal for Interdisciplinary Studies, pp.7061-7080

Scrivener, J. 2005. Learning Teaching. Oxford: McMillan Education. 